\title{
Is MYBPC3 linked to bicuspid aortic valve?
}

\author{
Talha Niaz ${ }^{1}$, Donald J. Hagler ${ }^{1,2,3}$ \\ ${ }^{1}$ Division of Pediatric Cardiology, Department of Pediatrics, Mayo Clinic, Rochester, Minnesota, USA; ${ }^{2}$ Department of Medicine, Mayo Clinic, \\ Rochester, Minnesota, USA; ${ }^{3}$ Department of Cardiovascular Diseases, Mayo Clinic, Rochester, Minnesota, USA \\ Correspondence to: Donald J. Hagler, MD. Professor of Pediatrics and Medicine, Divisions of Pediatric Cardiology and Cardiovascular Diseases, Mayo \\ Clinic College of Medicine, 200 First Street SW, Rochester, MN 55905, USA. Email: hagler.donald@mayo.edu. \\ Comment on: Zhao X, Hou C, Xiao T, et al. An interesting Mybpc3 heterozygous mutation associated with bicuspid aortic valve. Transl Pediatr \\ 2020;9:610-8
}

Submitted Dec 26, 2020. Accepted for publication Jan 11, 2021.

doi: $10.21037 /$ tp-20-477

View this article at: http://dx.doi.org/10.21037/tp-20-477

Bicuspid aortic valve (BAV) is a heterogeneous disease with variable phenotypes encompassing valvular disease and aortopathy. Although a majority of BAV patients are nonsyndromic and have isolated BAV disease, it can also occur as a feature of certain genetic syndromes such as Turner syndrome. The genetic architecture of BAV is also complex and multifactorial with reduced penetrance and variable expressivity among families (1). Unlike most Mendelian type disorders, where single gene may cause the disease, BAV seems to be caused or affected by multiple genes in association with the environmental and epigenetic factors $(1,2)$. Due to the complex polygenic and multifactorial nature of $\mathrm{BAV}$, the genetics of $\mathrm{BAV}$ still largely remain unraveled.

The study by Zhao et al. (3) describes a potential association of MYBPC3 (myosin binding protein $\mathrm{C}$ ) with $\mathrm{BAV}$. They have reported heterozygous mutation (Ala58Val) of MYBPC3 (c.173 C>T) in a BAV pedigree consisting of an 11-year-old proband and her affected father (described as aortic stenosis but not defined as a BAV) while the mother was unaffected and negative for mutation. The proband's echocardiogram does demonstrate a BAV with right and non-coronary cusp fusion. The major limitation of this study is the absence of experimental validation of this mutation. However, authors have vigorously attempted to counter this limitation by utilizing systematic bioinformatics and protein modeling assays that demonstrated reduced stability of MYBPC3 protein with this reported mutation. Moreover, they have also reported the expression of $M Y B P C 3$ mutation in the family, demonstrating that the levels of mRNA and MYBPC3 protein in the proband and affected father were almost half as compared to the unaffected mother who was negative for the mutation.

The MYBPC3 gene has primarily been described among patients with hypertrophic cardiomyopathy (4) in addition to left ventricular non-compaction (5) and dilated cardiomyopathy (6). The relationship to structural valve disease is not as easily explained. Although it has not been previously linked to BAV, recently emerging evidence has suggested some potential associations. Notably, Theis et al. (7) recently described a pathogenic $M Y B P C 3$ nonsense variant in a three generational family of a proband with hypoplastic left heart syndrome, father with left ventricular non-compaction, and two fourth-degree relatives with hypertrophic cardiomyopathy. Interestingly, the brother of this proband, who did not have genetic data available, had died during infancy from complications related to BAV, coarctation of the aorta and mild hypoplasia of left ventricle. Unfortunately, the lack of genetic or pathologic studies in this sibling leaves this observation only open to speculation.

Therefore, the reports by Theis et al. and Zhao et al. suggest a rare but potential role of MYBPC 3 in the structural left heart lesions like BAV that needs to be further validated and studied in experimental models.

\section{Acknowledgments}

Funding: None.

\section{Footnote}

Provenance and Peer Review: This article was commissioned 
by the editorial office, Translational Pediatrics. The article did not undergo external peer review.

Conflicts of Interest: Both authors have completed the ICMJE uniform disclosure form (available at http://dx.doi. org/10.21037/tp-20-477). The authors have no conflicts of interest to declare.

Ethical Statement: The authors are accountable for all aspects of the work in ensuring that questions related to the accuracy or integrity of any part of the work are appropriately investigated and resolved.

Open Access Statement: This is an Open Access article distributed in accordance with the Creative Commons Attribution-NonCommercial-NoDerivs 4.0 International License (CC BY-NC-ND 4.0), which permits the noncommercial replication and distribution of the article with the strict proviso that no changes or edits are made and the original work is properly cited (including links to both the formal publication through the relevant DOI and the license). See: https://creativecommons.org/licenses/by-nc-nd/4.0/.

\section{References}

1. Bravo-Jaimes K, Prakash SK. Genetics in bicuspid

Cite this article as: Niaz T, Hagler DJ. Is MYBPC3 linked to bicuspid aortic valve? Transl Pediatr 2021;10(2):223-224. doi: $10.21037 / \mathrm{tp}-20-477$ aortic valve disease: Where are we? Prog Cardiovasc Dis 2020;63:398-406.

2. Prakash SK, Bossé Y, Muehlschlegel JD, et al. A roadmap to investigate the genetic basis of bicuspid aortic valve and its complications: insights from the International BAVCon (Bicuspid Aortic Valve Consortium). J Am Coll Cardiol 2014;64:832-9.

3. Zhao X, Hou C, Xiao T, et al. An interesting Mybpc3 heterozygous mutation associated with bicuspid aortic valve. Transl Pediatr 2020;9:610-8.

4. Marian AJ, Braunwald E. Hypertrophic Cardiomyopathy: Genetics, Pathogenesis, Clinical Manifestations, Diagnosis, and Therapy. Circ Res 2017;121:749-70.

5. Probst S, Oechslin E, Schuler P, et al. Sarcomere gene mutations in isolated left ventricular noncompaction cardiomyopathy do not predict clinical phenotype. Circ Cardiovasc Genet 2011;4:367-74.

6. Haas J, Frese KS, Peil B, et al. Atlas of the clinical genetics of human dilated cardiomyopathy. Eur Heart J 2015;36:1123-35a.

7. Theis JL, Hu JJ, Sundsbak RS, et al. Genetic Association between Hypoplastic Left Heart Syndrome and Cardiomyopathies. Circ Genom Precis Med 2020. [Epub ahead of print]. doi:10.1161/CIRCGEN.120.003126. 